\title{
Landasan Teori Pendidikan Karakter Berbasis Pendidikan Agama Islam
}

\author{
Aan Hasanah \\ Universitas Islam Negeri (UIN) Sunan Gunung Djati Bandung \\ E-mail: aan.hasanah@uinsgd.ac.id \\ Bambang Samsul Arifin \\ Universitas Islam Negeri (UIN) Sunan Gunung Djati Bandung \\ Daryaman \\ Institut Agama Islam Darussalam (IAID) Ciamis \\ Janatun Firdaus \\ Universitas Islam Negeri (UIN) Sunan Gunung Djati Bandung \\ Dhika Kameswara \\ Universitas Islam Negeri (UIN) Sunan Gunung Djati Bandung
}

\begin{abstract}
Character education is not only a focus in the world of education in general, but in the view of Islam Character education is one of the important teachings that must be carried out by every individual Muslim. Character education is an important thing to be known, owned and practiced by humans. Character education in Indonesia has long been rooted in educational traditions. The ideal human being is one who has the power of reason and noble character. That is the man who will save himself, his family, nation, and country. The research method used is a qualitative method where the researcher's activities include understanding, analyzing and conducting a more accurate study with conceptualization and implementation of character education foundations. Education must understand efforts to cultivate intelligence in the form of thoughts both in the minds of students, appreciation and understanding in reason and practice in the form of behavior. The axiological foundation of character education will equip educators to think clearly about the relationship between life goals and character education so that they will be able to provide guidance in developing an educational program related to the realities of the global world.
\end{abstract}

Keywords: Character education, theoretical foundation. 


\section{PENDAHULUAN}

Menurut Abdul Majid, karakter sama dengan akhlak dalam pandangan Islam. Akhlak dalam pandangan Islam ialah kepribadian. Kepribadian itu komponennya tiga yaitu pengetahuan, sikap dan perilaku (Majid, 2017: iv).

Dalam pandangan Islam, nilai-nilai akhlak atau karakter merupakan salahsatu ajaran penting yang harus dimiliki oleh setiap individu umat Islam. Bahkan dalam salahsatu haditsnya, Rasulullah SAW menegaskan misi utama beliau diutus oleh Allah SWT adalah untuk menyempurnakan akhlak manusia.

$$
\text { إِنَّمَا بُعِثْتُ لَأَتَمِّمَ مَكَارمَ الأخْلْاَق }
$$

Artinya: Sesungguhnya saya diutus bertujuan untuk menyempurnakan akhlak yang mulia (Musnad Imam Ahmad, 1976: 75).

Rasulullah SAW sebagai orang yang diberi tugas untuk menyempurnakan akhlak manusia, maka Rasulullah SAW dijadikan oleh Allah SWT sebagai cerminan akhlak mulia bagi umat manusia. Sebagaimana firman Allah SWT, "Sungguh, pada pribadi Rasulullah, kamu dapatkan teladan yang agung bagi orang-orang yang mengharap rido Allah, hari kemudian dan yang banyak mengingat-Nya (Q.S. AlAhzab [33]:21).

Mengapa Rasulullah SAW dijadikan oleh Allah SWT sebagai suri tauladan yang mulia bagi umat manusia, karena Rasululllah SAW merupakan gambaran hidup mengenai semua ajaran Allah SWT dalam Al Quran. Hal ini, sebagaimana penjelasan hadits yang diriwayatkan oleh Imam Ahmad no 23460:

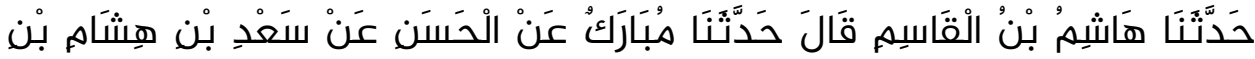

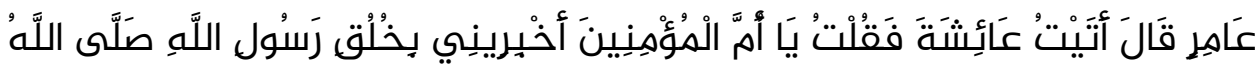

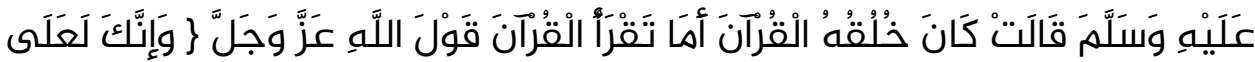

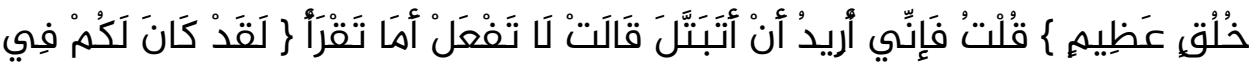

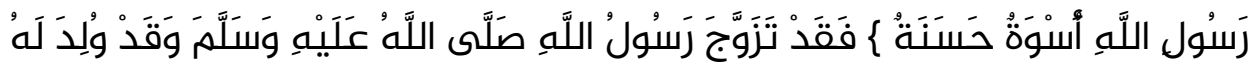
Artinya: Telah menceritakan kepada kami Hasyim bin Al-Qasim, dia berkata; telah menceritakan kepada kami Mubarak, dari Al-Hasan, dari Sa'ad bin Hisyam bin Amir, dia berkata; saya mendatangi Aisyah seraya berkata; "Wahai Ummul Mukminin! Kabarkanlah kepadaku mengenai akhlak Rasulullah!” (Aisyah) Berkata; "Akhlak beliau adalah Al Quran, bukankah engkau telah membaca Al Quran pada firman Allah Azzawajalla, Sesungguhnya engkau (Muhammad) memiliki akhlak yang agung." Saya (Sa'ad bin Hisyam bin Amir) Berkata; "Sungguh saya ingin membujang." (Aisyah) Berkata; "Jangan kamu lakukan, sungguh pada diri Rasulullah telah ada suri tauladan yang baik. Dan Rasulullah Shallallahu'alaihiwasallam juga menikah dan mempunyai anak." 


\section{BESTARI}

Vol. 18, No. 1, 2021

p-ISSN 1907-1337; e-ISSN 2807-6532

Untuk mencapai kemuliaan karakter, salahsatu cara mendapatkannya adalah dengan jalur pendidikan. Sebagaimana disampaikan oleh Ahmad Tafsir diatas, bahwasanya salahsatu komponen karakter adalah pengetahuan.

Oleh karena itu, pendidikan karakter merupakan hal penting untuk diketahui, dimiliki dan diamalkan oleh manusia.

Pendidikan adalah suatu proses pemindahan atau transformasi pengetahuan ataupun pengembangan potensi-potensi yang dimiliki oleh subjek didik untuk mencapai perkembangan secara optimal, serta membudayakan manusia melalui transpormasi nilai-nilai yang utama (Bashori Muchsin dan Abdul Wahid, 2009: 1).

Pendidikan merupakan bagian penting dari kehidupan manusia yang tidak pernah bisa ditinggalkan. Sebagai sebuah proses, ada dua asumsi yang berbeda mengenai pendidikan dalam kehidupan manusia. Pertama, pendidikan bisa dianggap sebagai sebuah proses yang terjadi secara tidak disengaja atau berjalan secara alamiah. Kedua, pendidikan bisa dianggap sebagai proses yang terjadi secara sengaja, direncanakan, didesain, dan diorganisasikan berdasarkan aturan yang berlaku, terutama perundang-undangan yang dibuat atas dasar kesepakatan masyarakat (Fatchul Mu'in, 2011: 287-288)

Apalagi saat ini sudah memasuki zaman modern, yang ditandai dengan perkembangan teknologi dan informasi yang cepat dalam berbagai aspek kehidupan termasuk dalam bidang pendidikan. Pendidikan merupakan suatu upaya untuk menjembatani masa sekarang dan masa yang akan datang dengan jalan memperkenalkan pembaharuan-pembaharuan yang cenderung mengejar efisiensi dan efektivitas (Udin Syaefudin, 2009: 1). Namun sangat disesalkan ternyata perkembangan teknologi dan informasi telah membawa bangsa kita mengalami krisis yang berkepanjangan dalam hal akhlak dan moral.

Saat ini di negara kita sudah memberilakukan kurikulum berkarakter. Karakter artinya mempunyai kualitas positif seperti peduli, adil, jujur, hormat terhadap sesama, dan bertanggungjawab (Barbara A. Lewis. 2004: 6). Pendidikan karakter di Indonesia telah lama berakar dalam tradisi pendidikan. Salah satunya dalam bahasa Ki Hadjar Dewantara, yang mengatakan bahwa pendidikan adalah upaya untuk memajukan pertumbuhan budi pekerti (kekuatan batin, karakter), pikiran (intellect), dan tubuh anak didik, agar mereka sebagai manusia dan sebagai anggota masyarakat dapat mencapai keselamatan dan kebahagiaan lahir batin. Orang pintar tanpa budi pekerti luhur (karakter tangguh) akan bahaya, namun orang yang berbudi luhur tetapi tidak pintar juga kurang berguna. Oleh karena itu, manusia ideal adalah yang pintar dan berbudi pekerti yang luhur. Itulah manusia yang akan menyelamatkan dirinya, keluarga, bangsa, dan negaranya (Suparman Sumahamijaya, 2003: 33-34). 
Ada beberapa penyebab rendahnya pendidikan karakter, diantaranya adalah: pertama, sistem pendidikan yang kurang menekankan pembentukan karakter, tetapi lebih menekankan pengembangan intelektual. Kedua, kondisi lingkungan yang kurang mendukung pembentukan karakter yang baik (Furqan Hidayatullah, 2010: 15)

Berdasarkan latarbelakang diatas, penulis mencoba untuk menggali mengenai landasan teori pendidikan karakter berkenaan dengan konseptualisasi dan implementasi landasan pendidikan karakter

\section{METODE}

Metode penelitian yang dipergunakan dalam penelitian ini adalah metode kualitatif. Pendekatan penelitian kualitatif sering disebut sebagai metode penelitian naturalistik karena penelitiannya dilakukan pada kondisi yang alamiah (natural setting). Dalam penelitian kualitatif unsur kecermatan dan langkah yang sistematis memegang peranan sangat penting. Dengan menggunakan pendekatan kualitatif diharapkan peneliti dapat lebih leluasa dalam memahami, menganalisa dan melakukan penelaahan lebih akurat berkenaan dengan konseptualisasi dan implementasi landasan pendidikan karakter.

\section{HASIL KAJIAN DAN PEMBAHASAN}

\section{Pengertian Karakter dan Pendidikan Karakter}

Istilah karakter yang dalam bahasa inggris character berasal dari istilah Yunani dari kata charassein yang berarti membuat tajam atau membuat dalam. Karakter juga dapat mengukir. Sifat utama ukiran adalah melekat kuat di atas benda yang diukir. Oleh karena itu, Wardani menyatakan bahwa karakter adalah ciri khas seseorang dan karakter tidak dapat dilepaskan dari konteks sosial budaya karena karakter terbentuk dalam lingkungan sosial budaya tertentu (Abdul Majid, 2013: 28)

Karakter menurut Kemendiknas, karakter adalah watak, tabiat, akhlak atau kepribadian seseorang, yang terbentuk dari hasil internalisasi berbagai kebijakan yang diyakini dan digunakan sebagai landasan sebagai cara pandang, berfikir, bersikap, dan bertindak (Pedoman sekolah, 2011: 8)

Mengacu pada berbagai pengertaian karakter yang dikemukakan di atas, maka dapat disimpulkan bahwa karakter adalah nilai dasar yang membangun peribadi seseorang, terbentuk baik karena pengaruh hereditas maupun pengaruh lingkungan, yang membedakannya dengan orang lain, serta diwujudkan dalam sikap dan perilakunya dalam kehidupan sehari-hari (Muchlas Samani, 2012: 43)

Sementara menurut Rahardjo, pendidikan karakter adalah suatu proses pendidikan yang holistik yang menghubungkan dimensi moral dengan ranah sosial dalam kehidupan peserta didik sebagai fondasi bagi 


\section{BESTARI}

Vol. 18, No. 1, 2021

p-ISSN 1907-1337; e-ISSN 2807-6532

terbentuknya generasi yang berkualitas yang mampu hidup mandiri dan memilliki prinsip suatu kebenaran yang dapat dipertanggung jawabkan (Syamsul Kurniawan, 2013: 30)

\section{Konsep Pendidikan Akhlak}

Dalam Islam, karakter disebut juga al-khuluq, bentuk tunggalnya adalah akhlaq, yaitu kondisi batiniah (dalam) bukan al-sajiyah. Khuluq yaitu kondisi (hay'ah) dalam jiwa (nafs) dan suci (rasikhah), dan dari kondisi itu tumbuh suatu aktivitas yang mudah tanpa memerlukan pemikiran dan pertimbangan terlebih dahulu (Tim LPP SDM, 2010: 68). Tentang akhlak ini Imam Al-Qosimi mengutip definisi akhlak dari Imam Al-Ghazali sebagai berikut :

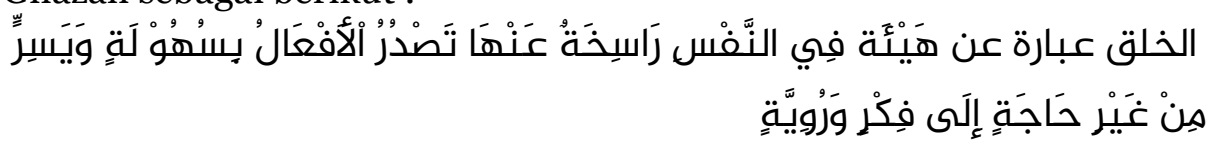

Akhlaq adalah sifat yang tertanam dalam jiwa (manusia) yang melahirkan perbuatan-perbuatan dengan mudah tanpa memerlukan pemikiran maupun pertimbangan (Muhammad Jamaluddin al-Qosimi, tt: 177).

Dalam hal ini, khuluq dapat disamakan dengan karakter yang masing-masing individu memiliki keunikan tersendiri, yang berbeda dengan yang lainnya. Dalam terminologi psikologi, karakter adalah watak, peranggi, sifat dasar yang khas, satu sifat atau kualitas yang tetap terus menerus dan kekal yang dapat dijadikan ciri untuk mengidentifikasi seseorang individu.

Pendidikan akhlak sebagaimana dirumuskan oleh Ibn Miskawaih merupakan upaya ke arah terwujudnya sikap batin yang mampu mendorong secara spontan lahirnya perbuatan - perbuatan yang bernilai baik dari seseorang. Dalam pendidikan akhlak ini, kriteria benar dan salah merujuk pada Al Quran dan Sunnah sebagai sumber ajaran Islam (Abdul Majid dan Dian Andayani, 2017: 10).

\section{Pendidikan Moral}

Perkataan "moral" berasal dari bahasa latin "Mores" kata jama dari "Mos" yang berarti adat kebiasaan. Dalam bahasa Indonesia moral diterjemahkan dengan arti susila. Ya'kub menjelaskan bahwa yang dimaksud dengan moral ialah sesuai dengan ide-ide yang umum diterima tentang tindakan manusia mana yang baik dan wajar. Jadi sesuai dengan ukuran tindakan-tindakan yang oleh umum diterima, yang meliputi kesatuan sosial dan lingkungan tertentu (Ya'kub, 1983: 14).

Terminologi pendidikan moral (moral education) dalam dua dekade terakhir secara umum digunakan untuk menjelaskan penyelidikan isu-isu etika di ruang kelas dan sekolah. Pengajaran etika dalam pendidikan moral lebih cenderung pada penyampaian nilai-nilai yang benar dan salah. Sedangkan penerapan nilai-nilai itu dalam kehidupan 
pribadi, keluarga dan masyarakat hanya bersifat normatif kurang bersinggungan dengan ranah afektif dan psikomotorik (Abdul Majid dan Dian Andayani, 2017: 19).

\section{Pendidikan Budi Pekerti}

Esensi dan makna Budi Pekerti sama dengan pendidikan moral dan pendidikan akhlak. Dalam konteks pendidikan di Indonesia pendidikan budi pekerti adalah pendidikan nilai, yakni pendidikan nilai yang luhur yang bersumber dari budaya bangsa Indonesia, dalam rangka membina kepribadian generasi muda (Tim Penyusun Pendidikan Budi Pekerti, 2001: 27).

Dalam hal ini, pengertian budi pekerti dapat dilihat dari berbagai aspek, yaitu secara epistimologi budi pekerti maknanya penampilan diri yang berbudi. Secara leksikal budi pekerti adalah tingkah laku, perangai, akhlak dan watak. Jadi budi pekerti dapat diartikan baik hati (Andewi, 2001: 59).

\section{Tujuan Pendidikan Karakter}

Menurut Dharma Kesuma (2011: 5), Pendidikan karakter bertujuan untuk mutu proses dan hasil pendidikan yang mengarah pada pembentukan karakter dan akhlak mulia peserta didik secara utuh, terpadu dan seimbang sesuai dengan standar kompetensi lulusan pada setiap satuan pendidikan. Melalui pendidikan karakter peserta didik diharapkan mampu secara mandiri meningkatkan dan menggunakan pengetahuannya, mengkaji dan menginternalisasikan serta mempersonalisasikan nilai nilai karakter dan akhlak mulia sehingga terwujud dalam perilaku sehari-hari

Dalam hubungannya dengan pendidikan, pendidikan karakter dapat dimaknai sebagai pendidikan nilai, pendidikan budi pekerti, pendidikan moral, pendidikan watak yang bertujuan mengembangkan kemampuan siswa untuk memberikan keputusan baik-buruk, memelihara kebaikan, mewujudkan dan menebarkan kebaikan dalam kehidupan sehari-hari dengan sepenuh hati.

Adapun tujuan dari pendidikan karakter menurut Anas Salahudin dan Irwanto Alkrienciechie (2013: 43), sesungguhnya jika dihubungkan dengan falsafah Negara Republik Indonesia adalah mengembangkan karakter peserta didik agar mampu mewujudkan nilai nilai luhur Pancasila.

Pendidikan karakter merupakan upaya pembimbingan perilaku siswa agar mengetahui, mencintai, dan melakukan kebaikan. Jadi, fokusnya pada tujuan-tujuan etika melalui proses pendataan apresiasi dan pembiasaan. Secara teoretis, karakter seseorang dapat diamati dari tiga aspek, yaitu : mengetahui kebaikan (knowing the good), mencintai kebaikan (loving the good) dan melakukan kebaikan (doing the good). 


\section{BESTARI}

Vol. 18, No. 1, 2021

p-ISSN 1907-1337; e-ISSN 2807-6532

\section{Mekanisme Pembentukan Karakter}

Unsur terpenting dalam pembentukan karakter adalah pikiran karena pikiran yang didalamnya terdapat seluruh program yang terbentuk dari pengalaman hidupnya, merupakan pelopor segalanya. Dalam berbagai literatur ditemukan bahwa kebiasaan yang dilakukan secara berulang-ulang yang didahului oleh kesadaran dan pemahaman akan menjadi karakter seseorang (Abdul Majid dan Dian Andayani, 2017: 17).

Dalam literatur Islam ditemukan bahwa faktor gen/keturunan diakui sebagai salahsatu faktor yang mempengaruhi pembentukan karakter. Misalnya pengakuan Islam tentang alasan memilih calon istri atas dasar faktor keturunan.

Selain itu, faktor yang berdampak pada karakter seseorang selain dari gen adalah faktor makanan, teman, orang tua dan tujuan merupakan faktor terkuat dalam mewarnai karakter seseorang (Munir, 2010: 9).

Karakter tidak tercipta begitu saja tanpa adanya proses yang terjadi di dalamnya. Sebagaimana makna karakter di awal yaitu sesuatu yang terukir. Maka proses terukirnya karakter seseorang diawali dengan rangkaian proses berikut ini :

1. Pengenalan

Maksud dari pengenalan ini adalah seorang anak diperkenalkan tentang hal-hal positif atau yang baik dari lingkungan, maupun keluarga. Contohnya anak diajarkan tentang kejujuran, tenggang rasa, gotong royong, bertanggung jawab dan sebagainya. Tahapan ini bertujuan untuk menanamkan hal positif dalam memorinya.

2. Pemahaman

Selanjutnya adalah pemahaman, maksud dari pemahaman disini adalah kita memberikan pengarahan atau pengertian tentang perbuatan baik yang sudah kita kenalkan kepada si anak. Tujuannya agar dia tahu dan mau melakukan hal tersebut dalam keluarga ataupun dalam masyarakat.

3. Penerapan

Setelah si anak telah paham tentang perbuatan baik yang telah kita ajarkan langkah yang selanjutnya adalah penerapan. Maksud dari penerapan disini adalah kita memberikan kesempatan pada anak untuk menerapkan perbuatan baik yang telah kita ajarkan.

4. Pengulangan/Pembiasaan

Maksud dari pengulangan disini adalah setelah si anak telah paham dan menerapkan perbuatan baik yang telah kita kenalkan kemudian kita lakukan pembiasaan, dengan cara melakakuan hal baik tersebut secara berualang ulang agar si anak terbiasa melakukan hal baik tersebut.

5. Pembudayaan 
Pembudayaan disini harus diikuti dengan adanya peran serta masyarakat untuk ikut melakukan dan medukung terciptanya pembentukan karakter baik yang telah diterapkan dalam masyarakat maupun di dalam keluarga. Adanya hukuman jika tidak ikut pembudayaan tersebut akan memunculkan motivasi untuk ikut dan berperan serta dalam pembudayaan karakter yang baik dan positif dalam masyarakat.

6. Internalisasi Menjadi Karakter

Karakter seseorang akan semakin kuat jika ikut didorong adanya suatu ideologi atau believe. Jika semua sudah tercapai maka akan ada kesadaran dalam diri seseorang untuk melakukan hal yang baik tersebut tanpa adanya paksaan atau dorongan untuk melakukannya. Selain itu adanya faktor internal dalam masyarakat atau keluarga akan mempengaruhi karakter seseorang.

Karakter setiap manusia terbentuk melalui 5 Tahap yang saling berkaitan. Lima tahapan itu adalah :

1. Adanya nilai yang diserap seseorang dari berbagai sumber, seperti agama, ideologi, pendidikan dll.

2. Nilai membentuk pola fikir seseorang yang secara keseluruhan keluar dalam bentuk rumusan visi.

3. Visi turun ke wilayah hati membentuk suasana jiwa yang secara keseluruhan membentuk mentalitas.

4. Mentalitas mengalir memasuki wilayah fisik dan melahirkan tindakan yang secara keseluruhan disebut sikap.

5. Sikap-sikap dominan dalam diri seseorang yang secara keseluruhan mencitrai dirinya adalah apa yang disebut sebagai karakter atau kepribadian

Proses pembentukan mental tersebut menunjukan keterkaitan antara fikiran, perasaan dan tindakan. Dari akal terbentuk pola fikir, dari fisik terbentuk menjadi perilaku. Cara berfikir menjadi visi, cara merasa menjadi mental dan cara berprilaku menjadi karakter. Apabila hal ini terjadi terus menerus akan menjadi sebuah kebiasaan.

\section{Nilai-nilai Pendidikan Karakter}

Menurut Kementrian Pendidikan Nasional yang dikutip oleh Anas Sholehuddin, nilai karakter bangsa terdiri atas sebagai berikut:

a. Religius, yaitu sikap dan penlaku yang patuh dalam melaksanakan ajaran agama yang dianutnya, toleran terhadap pelaksanaan ibadah agama lain

b. Jujur, yaitu perilaku yang didasarkan pada upaya menjadikan dirinya sebagai orang yang selalu dapat dipercaya dalam perkatan, tindakan, dan pekerjaan.

c. Toleransi, yaitu sikap dan tindakan yang menghargai perbedaan agama, suku, etnis, pendapat, sikap, dan Tindakan orang lain yang berbeda dari dirinya. 


\section{BESTARI}

Vol. 18, No. 1, 2021

p-ISSN 1907-1337; e-ISSN 2807-6532

d. Disiplin, yaitu Tindakan yang menunjukan prilaku tertib dan patuh pada berbagai ketentuan dan peraturan.

e. Kerja Keras, yaitu prilaku yang menunjukan upaya sungguh-sungguh dalam mengatasi berbagai hambatan belajar dan tugas, serta menyelesaikan tugas dengan sebaik baiknya.

f. Kreatif, yaitu berfikir dan melakukan sesuatu untuk menghasilkan cara atau hasil baru dari sesuati yang telah dimiliki.

g. Mandiri, yaitu sikap dan prilaku yang tidak mudah bergantung pada orang lain dalam menyelesaikan tugas-tugas.

h. Demokratis, yaitu cara berpikir, bertindak, dan berwawasan yang menempatkan kepentingan bangsa dan negara diatas kepentingan diri dan kelompoknya.

i. Rasa ingin tahu, yaitu sikap dan Tindakan yang selalu berupaya untuk mengetahui lebih mendalam dan meluas dari sesuatu yang dipelajarinya, dilihat, dan didengar.

j. Semangat kebangsaan, yaitu cara berpikir, bertindak, dan berwawasan yang menempatkan kepentingan bangsa dan negara di atas kepentingan diri dan kelompoknya.

k. Cinta tanah air, yaitu cara berpikir, bersikap, dan berbuat yang menunjukkan kesetiaan. kepedulian, dan penghargaan yang tinggi terhadap bahasa, lingkungan fisik, sosial, budaya, ekonomi, dan politik bangsa.

1. Menghargai prestasi. yaitu tindakan yang memperlihat rasa senang berbicara. bergaul. dan bekerja sama dengan orang lain.

m. Bersahabat/komunikatif. yaitu tindakan yang memperlihatkan rasa senang berbicara, bergaul, dan bekerja sama dengan orang lain.

n. Cinta damai, yaitu sikap. perkataa, dan tindakan yang menyebabkan orang lain merasa senang dan aman atas kehadiran dirinya.

o. Gemar membaca, yaitu kebiasaan menyediakan waktu untuk membaca berbagai bacaan yang memberikan manfaat bagi dirinya.

p. Peduli lingkungan, yaitu sikap dan tindakan yang berupaya mencegah kerusakan lingkungan alam di sekitarnya, dan mengembangkan upaya-upaya untuk memperbaiki kerusakan alam yang sudah terjadi.

q. g. Peduli sosial, yaitu sikap dan tindakan yang selalu ingin memberi bantuan pada orang lain dan masyarakat yang membutuhkan.

r. Tanggung jawab, yaitu sikap dan perilaku seseorang untuk melaksanakan tugas dan kewajibannya, yang seharusnya dia lakukan terhadap diri sendiri, masyarakat, lingkungan (alam, karakter dunulai dari dalam sosial dan budaya), negara dan Tuhan Yang Maha Esa.”

Nilai-nilai yang dikembangkan dalam pendidikan karakter di Indonesia diidentifikasi berasal dari empat sumber yaitu agama, Pancasila, budaya, dan tujuan pendidikan nasional. Sedangakan nilainilai yang terbentuk dari sumber tersebut adalah religius, jujur, toleransi, disiplin, kerja keras, kreatif, mandiri, demokratis, rasa ingin tahu, semangat kebangsaan, cinta tanah air, menghargai prestasi, 
bersahabat/komunikatif, cinta damai, gemar membaca, peduli lingkungan, peduli sosial, tanggung jawab (Muchlas Samani 2014: 52).

Dalam referensi islam, nilai yang sangat terkenal dan melekat mencerminkan akhlak/perilaku yang luar biasa tercermin pada Nabi Muhammad SAW:

1) Sidiq yang berarti benar, mencerminkan bahwa Rasulullah SAW berkomitmen pada kebenaran, selalu berkata dan berbuat benardan berjuang untuk menegakkan kebenaran.

2) Amanah yang berarti jujur atau terpercaya, mencerminkan bahwa apa yang dikatakan dan apa yang dilakukan Rasulullah dapat dipercaya oleh siapa pun baik kaum muslimin maupun kaum nonmuslim.

3) Fatonah yang berarti cerdas/pandai, arif, luas wawasan, terampil, dan professional. Artinya perilaku Rasulullah dapat dipertanggung jawabkan kehandalanya dalam memecahkan masalah.

4) Tablig yang bermakna komunikatif menverminkan bahwa siapa pun yang menjadi lawan bicara Rasulullah, maka orang tersebut akan mudah memahami apa yang dibicarakan/dimaksudkan oleh Rasulullah (Dharma Kesuma, dkk, 2013: 11-12)

Dalam Grand Design Pendidikan Karakter diungkapkan nilai-nilai yang akan dikembangkan dalam budaya satuan pendidikan formal dan nonformal, dengan penjelasanya adalah sebagai berikut:

1) Jujur, menyatakan apa adanya, terbuka, konsisten antara apa yang dikatajkan dan dilakukan, berani karena benar, dapat dipercaya dan tidak curang.

2) Tanggung jawab, melakukan tugas sepenuh hati, bekerja dengan etos kerja yang tinggi, berusaha keras untuk mencapai prestasi terbaik, mampu mengontrol diri dan mengatasi stres, berdisiplin diri, akuntabel terhadap pilihan dan keputusan yang diambil.

3) Cerdas, berpikir secara cermat dan tepat, bertindak dengan penuh perhitungan, rasa ingin tahu yang tingi, berkomunikasi efektif dan empatik, bergaul secara santun, menjunjung kebenaran dan kebajikan, mencintai Tuhan dan lingkungan.

4) Sehat dan Bersih, menghargai ketertiban, keteraturan, kedisiplinan, terampil, menjaga diri dan lingkungan, menerapkan pola hidup seimbang.

5) Peduli, memperlakukan orang lain dengan sopan, bertindak santun, toleran terhadap perbedaan, tidak suka menyakiti orang lain, mau mendengar orang lain, mau berbagi, tidak merendahkan orang lain, tidak mengambil keuntungan dari orang lain, mampu bekerja sama, mau terlibat dalam kegiatan masyarakat, menyayangi manusia dan makhluk lain, setia, cinta damai dalam menghadapi persoalan.

6) Kreatif, mampu menyelesaikan masalah secara inovatif, luwes, kritis, berani mengambil keputusan dengan cepat dan tepat, menampilkan sesuatu secara luar biasa (unik), memiliki ide baru, ingin terus berubah, dapat membaca situasi dan memanfaatkan peluang baru. 


\section{BESTARI}

Vol. 18, No. 1, 2021

p-ISSN 1907-1337; e-ISSN 2807-6532

7) Gotong royong, mau bekerja sama dengan baik, berprinsip bahwa tujuan akan lebih mudah dan cepat tercapai jika dikerjakan bersamasama, tidak memperhitungkan tenaga untuk saling berbagi dengan sesama, mau mengembangkan potensi diri untuk dipakai saling berbagi agar mendapatkan hasil yang terbaik, tidak egoistis (Muchlas Samani, 2014: 51)

\section{SIMPULAN}

Terminologi yang mendefinisikan mengenai perilaku manusia mempunyai beberapa macam varian. Term tersebut ada yang menggunakan istilah karakter, akhlak, moral, budi pekerti dan etika. Akan tetapi dalam dunia pendidikan, terminologi karakter lebih populer penggunaannya dibandingkan dengan term kata lain.

Pendidikan karakter harus dipahami sebagai upaya penanaman kecerdasan bersikap baik dalam pikiran peserta didik, penghayatan dan pemahaman dalam bentuk akal budi dan pengamalan dalam bentuk perilaku. Peserta didik diharapkan dapat mengamalkan nilai-nilai luhur yang menjadi jati diri sebagai manusia yang menjungjung nilai-nilai karakter atau moral.

Landasan ontologi dalam pendidikan karakter lebih menekankan pada aspek hakikat keberadaan, yang dimaksud keberadaan di sini adalah keberadaan pendidikan karakter. Epistemologi pendidikan karakter merupakan pencarian metode dan model pendidikan karakter yang tepat untuk diterapkan kepada peserta didik. Landasan epistemologi pendidikan karakter merupakan fenomenologi dengan segala persyaratan dan perangkatnya yang disebut sebagai komponen ilmu pendidikan karakter. Landasan aksiologis pendidikan karakter akan membekali para pendidik berpikir klarifikatif tentang hubungan antara tujuan-tujuan hidup dan pendidikan karakter sehingga akan mampu memberi bimbingan dalam mengembangkan suatu program pendidikan yang berhubungan secara realitas dengan konteks dunia global.

\section{DAFTAR PUSTAKA}

Abdul Majid dan Dian Andayani, Pendidikan Karakter Perspektif Islam, Rosdakarya, Bandung, 2013

Barbara A. Lewis. Character Building untuk Anak-Anak, Karisma, Batam. 2004.

Bashori Muchsin dan Abdul Wahid, Pendidikan Islam Kontemporer, PT. Refika Aditama, Bandung, 2009. 
Dharma Kesuma, dkk, Pendidikan Karakter Kajian Teori dan Praktik di Sekolah (Bandung: PT Remaja Rosdakarya, 2013)

Fatchul Mu'in, Pendidikan Karakter Konstruksi Teoretik dan Praktik, Ar-Ruzz Media, Jogjakarta, 2011.

Furqan Hidayatullah, Pendidikan Karakter: Membangun Peradaban Bangsa, Yuma Pustaka, Yogyakarta, 2010

Muchlas Samani dan Hariyanto, Konsep dan Model Pendidikan Karakter (Bandung: PT. Remaja Rosdakarya, 2014)

Muhammad Jamaluddin al-Qosimi, Ma'uidhah al-Mu'minin min Ihya Ulumuddin Juz II, Dar al-Haditsah, Kairo, tt.

Musnad Imam Ahmad, (Dar al-Fikir, Kairo, Mesir: 1976)

Pedoman sekolah, Pengembangan Pendidikan Budaya dan Karakter Bangsa, (Jakarta: Kementerian Pendidikan Nasional Badan Penelitian dan Pengembangan Pusat Kurikulum, 2011)

Suparman Sumahamijaya, et al, Pendidikan Karakter Mandiri dan Kewiraswastaan, Angkasa, Bandung.

Syamsul Kurniawan, Pendidikan Karakter: Konsepsi dan Implementasinya Secara Terpadu di Lingkungan Keluarga, Sekolah, Perguruan Tinggi, dan Masyarakat (Yogyakart: ArRuzz Media, 2013)

Tim LPP SDM, Ensiklopedi Pendidikan Islam Jilid 5, CV. Binamuda Ciptakreasi, Depok, 2010

Udin Syaefudin, Inovasi Pendidikan, Alfabeta, Bandung, 2009.

Zaini Dahlan, Qur'an Karim Dan Terjemahan Artinya, Yogyakarta, UII Press, 2020 